\title{
Gonad shielding in pelvic radiography: modern optimised X-ray systems might allow its discontinuation
}

\author{
Cécile R. L. P. N. Jeukens (D, Gerhard Kütterer, Pierre J. Kicken, Marij J. Frantzen, Jos M. A. van Engelshoven, \\ Joachim E. Wildberger and Gerrit J. Kemerink
}

\begin{abstract}
Objective: As gonad shielding is currently under debate, this study evaluates the practice, from its introduction in about 1905 until today.

Methods: The literature was searched for developments in shielding and insights into the effects of ionising radiation on gonads. Based on own pre-1927 dose reconstructions, reported doses after 1927, a 2015-report from the European Union and recent own measurements, the effects of technological evolution and optimisation on radiation dose and hereditary risk were assessed.

Results: In the 1900s, gonad shielding was first applied to prevent male sterility, but was discontinued when instrumental developments led to reduced radiation doses. In the 1950s, concerns about hereditary risks intensified and gonad shielding was recommended again, becoming routine worldwide. Imaging-chain improvements over time were considerable: in 2018, the absorbed dose was $0.5 \%$ of its 1905 value for the testes and $2 \%$ for the ovaries, our optimised effective dose a factor five lower than the value corresponding to the current EU diagnostic reference level, and the reduction in detriment-adjusted risk by shielding less than $1 \times 10^{-6}$ for women and $5 \times 10^{-6}$ for men.

Conclusions: Assessment of pelvic doses revealed a large reduction in radiation risks facilitated by technological developments. Optimisation likewise contributed, but unfortunately, its potential was never adequately exploited. Today, using a modern and optimised X-ray system, gonad shielding can be safely discontinued for women. For men, there might be a marginal benefit, but potential negative side-effects may well dominate. Discontinuation of gonad shielding seems therefore justifiable.
\end{abstract}

Keywords: Gonad shielding, Pelvic radiography, Gonad radiation dose, Hereditary radiation risk, Optimisation

\section{Key points}

- Gonad shielding originated around 1905 to prevent male sterility, but was discontinued after doses went down

- In the mid-1950s, gonad shields were reintroduced, now to reduce hereditary risks

- Technological evolution and optimisation lowered gonad doses to $0.5-2 \%$ of the 1905 values

- Today, after optimisation, the hereditary risk reduction is marginal at best $\left(<5 \times 10^{-6}\right)$

* Correspondence: cecile.jeukens@mumc.nl

Department of Radiology and Nuclear Medicine, Maastricht University

Medical Center, P. Debijelaan 25, 6229 HX Maastricht, The Netherlands
- Considering also negative side-effects, discontinuation of gonad shielding seems justifiable

\section{Introduction}

The benefit of gonad shielding in anteroposterior (AP) pelvic radiography is currently under debate. The ICRP (2013) [1] and IAEA (2018) [2] endorse this practice, whereas others, such as the Dutch guidelines [3], Marsh and Silosky [4] and the AAPM [5], no longer recommend it. Other authors dismiss gonad shielding partly or express their doubts about existing benefits [6-13]. This debate should ideally be decided by a quantitative analysis based on proper knowledge of radiation risks, reduction in hereditary risk by gonad shielding and the 
increase in risk caused by negative side-effects of shielding. The Dutch guidelines [3] provide steps in these directions, as does the work by Frantzen et al. [7].

This article aims at a missing, more complete assessment of benefits and risks of gonad shielding, from its beginning until now. To be addressed are the following: the histories of gonad shielding and perception of gonadal radiation risk, the evolution of the dose of a pelvic radiograph, imaging chain improvements and the decrease in detriment-adjusted risk by gonad shielding. The historical aspects are presented within 'Introduction", the other three in "Methods and materials, Results and Discussion'.

Perception of gonadal radiation risk: a historical overview The similarity between X-ray erythema, already observed in 1896 [14], and the erythema caused by ultraviolet radiation applied in the so-called Finsen therapy of skin diseases [15], probably led the way to therapeutic applications of X-rays. As early as 1901, Williams reported about a dozen benign and malignant skin afflictions which were treated with Xrays [16]. Amongst these were eczema of the scrotum, tuberculosis of the testes and pruritis ani [17-20]. Clearly, no barriers were felt at that time to expose the testes to very high radiation doses.

Already in 1896, X-rays had been used for "deep therapy" [21], albeit with limited success. In 1903, AlbersSchönberg studied the effect of X-rays on the testes, finding that male rabbits and guinea pigs could easily be sterilised, even without inducing dermatitis of the skin [22]. In 1905, Halberstaedter similarly found high radiation sensitivity for the ovaries of rabbits [23]. Temporary and permanent sterility of male operators of X-ray systems was reported not long thereafter [20].

Biological effects of radiation at the level of tissues, cells and chromosomes were also studied from the beginning. In 1906, Bardeen wrote an extensive overview of these experiments [24]. In his own studies on toads, he found that irradiated sperm, notwithstanding the apparently normal fertilisation of eggs, resulted in abnormal development. Damage to the chromosomes was the cause. The fact that radiation-induced mutations could also be inherited was proven by Muller in 1926 [25]. Mavor had already shown this in 1921 [26], but he was somehow not given the credits. Muller assumed no threshold in the induction of heritable mutations, a proposition still held today. Soon thereafter, concern for hereditary effects in radiology was expressed in the literature [27-31]. After World War II, the fear for radiation was fuelled by the effects observed in victims of the nuclear bombs on Hiroshima and Nagasaki. Apprehension grew further due to the increasing exposure to radiation, from medical applications, nuclear industry and, at that time, fall-out of nuclear bomb testing.
Even though no radiation-induced genetic effects had been observed, the ICRP worried about the accumulation of genetic mutations, leading in 1956 to the declaration: "Genetic damage assumes greater importance" and "Realising the importance and urgency of the matter..... to recommend in the near future a maximum permissible 'genetic dose'..." [32]. Soon afterwards, the genetically significant dose (GSD) was introduced as a measure for the annual radiation load of the genome of the whole population. UNSCEAR explained in 1958 "...., a genetically significant dose can be defined as the dose which, if received by every member of the population, would be expected to produce the same total genetic injury to the population as do the actual doses received by the various individuals" [33].

In 1958, the ICRP suggested a genetic dose limit of 5 rem $(50 \mathrm{mSv})$ per generation [32]. The GSD was assessed in numerous studies. In 1969, the ICRP informed "The genetically significant dose from medical diagnostic radiology has been determined for many countries and ranges between 10 and $60 \mathrm{mrad}$ per annum" (0.1-0.6 mGy/year) [34]. As such, over the 30 years usually considered for procreation, the genetic dose was lower than the ICRP limit and also lower than the dose due to natural radiation. The GSD has quietly disappeared from contemporary literature. The reasons are probably the non-alarming values and the smaller than feared hereditary effects. Cancer induction became the dominating concern [35].

Since 1977, the genetic risk is, together with the somatic risk, included in the effective dose equivalent $\left(H_{\mathrm{E}}\right)$, later redefined as the effective dose $(E)$. An earlier effort to combine genetic and somatic risk in a "Gesamtbelastung" was proposed by Frik in 1960 [36].

The changing insights into the risk of genetic effects are reflected in the decreasing tissue weighting factor for the gonads used in the calculation of the effective dose equivalent or effective dose: 0.25 in ICRP 26 (1977) [37], 0.20 in ICRP 60 (1990) [38] and 0.08 in ICRP 103 (2007) [35].

Table 1 shows some effects of X-rays on gonads (after ICRP 103) [35].

\section{Gonad shielding: its introduction, hardware and recommendations}

Since Röntgen's first X-ray experiments, lead $(\mathrm{Pb})$ was the preferred material for shielding. Unfortunately, lead contaminates hands and clothing and it creases after repeated use. In 1903, Holzknecht succeeded in covering lead foil with rubber, eliminating contamination as well as the formation of sharp folds and holes by repeated bending [39].

As early as 1905, Cramer [40] used gonad shielding during therapy on both male and female patients, as did 
Table 1 Estimates of the threshold absorbed dose for tissue effects in adult human gonads [35]

\begin{tabular}{lllll}
\hline Tissue & $\begin{array}{l}\text { Induction } \\
\text { of sterility }\end{array}$ & $\begin{array}{l}\text { Total dose in } \\
\text { single } \\
\text { exposure } \\
\text { (Gy) }\end{array}$ & $\begin{array}{l}\text { Total dose in } \\
\text { protracted } \\
\text { exposure (Gy) }\end{array}$ & $\begin{array}{l}\text { Annual dose rate } \\
\text { in protracted } \\
\text { exposure (Gy/year) }\end{array}$ \\
\hline Testes & Temporary & 0.15 & - & 0.4 \\
& Permanent & $3.5-6.0$ & - & 2.0 \\
Ovaries & Permanent & $2.5-6.0$ & 6.0 & $>0.2$ \\
\hline
\end{tabular}

Note: hereditary effects are assumed to be induced with no dose threshold

Halberstaedter [23] on females. In 1907, Kienböck recommended shielding of the testes whenever possible, both during diagnostic and therapeutic X-ray exposure [41]. Albers-Schönberg did the same in the 1910, 1913 and 1919 editions of his famous textbook "Die Röntgentechnik" [42]. The advice to shield the testes was absent, however, in the 1941-edition, appearing 20 years after his death with Grashey as editor [43]. Recommendations to shield the ovaries were not found in early literature on diagnostic radiology, as opposed to therapeutic radiology.

In 1954, the ICRP wrote with respect to radiology, referring to both male and female patients, "In all irradiations the gonads should be protected as much as possible by collimation of the beam or by protective screens." [44].

Many different types of gonad shielding were proposed: capsules for the testes [45-47], flat contact-type shields [47-51] and projection-type shields consisting of a shield mounted on a stand [52] or on a PMMA rotatable disk to be mounted on the diaphragm housing $[53,54]$. For more early designs and references, see Büchner [55], Stieve [49], Markó [56] and Grigg [57]. Even internal shielding of a foetus and the ovaries by introducing $\mathrm{BaSO}_{4}$ into the gastrointestinal tract has been proposed [58]. A selection of shields is shown in Fig. 1 [45-48, 52, 53, 55].

In general, contact shields prevail, with size and shape dependent on age and gender of the patient [47-51].

Endorsed by national and international bodies, gonad shielding became routine. ICRP 34 [59] states "The gonads of individuals with reproductive potential should be protected if they are within the primary beam or within $5 \mathrm{~cm}$ of it, and if the shielding does not exclude important diagnostic information or interfere with the study." Gonad shielding can lower the dose to the testes by about $95 \%$ and to the ovaries by about $50 \%$ [59]. The protection in females is less effective, mainly due to the large variation in the position of the ovaries, including areas far from the midline lying anterior to pelvic anatomy which must remain visible [6]. In practice, it is difficult to position the X-ray shield correctly, i.e. fully covering the target area but none of the bony pelvic structures: in a meta-analysis, based on 19 studies, the average of correctly positioned shields was found to be only $34 \%$ [60].

\section{Methods and materials \\ Radiation dose of an AP pelvic radiograph over time}

To appreciate the benefit of gonad shielding in pelvic radiography, knowledge of the dose incurred by the testes and ovaries is required. Therefore, dose information was sought from the start of radiology in 1896 up to 2018. Unfortunately, it turned out that effectively no explicit doses had been published before 1927. Exposure parameters were found in the literature, however, and these could be used for dose reconstruction with an estimated uncertainty of $40-60 \%$ (a typical dose reconstruction required about seven parameters, each with its own potential error, which explains the large uncertainty). After 1927, explicit doses were reported and these have been collected. All dose data, reconstructed and retrieved, were presented as "entrance surface air kerma including backscatter" (ESAK). Because of its large size, this study was published separately [61]. Using the ESAK values obtained, it is possible to estimate effective dose and gonad doses by first converting the ESAK values to kerma free in air (KfiA) (by dividing ESAK by the backscatter factor) and then using the KfiA as input in PCXMC [62, 63]. PCXMC is a Monte Carlo programme for computing patient doses in radiology.

Doses were calculated for three landmark times. For the time at which gonad shielding was introduced, three representative results from 1904-1906 were averaged [64-67]. Similarly, for the time gonad shielding was reintroduced in the mid-1950s, the 1958 cases from Janker [68] and Lincoln [69] were assessed. Finally, for recent times, data from one European and two Dutch sources have been used:

- The most common European diagnostic reference level (DRL) for anteroposterior (AP) pelvic radiography, specified by a kerma area product (KAP) of $3.0 \mathrm{~Gy} \mathrm{~cm}^{2}$ [70], for doses around 2010.

- In Dutch surveys of 2015, 2016 and 2017, the average KAP was, respectively, $1.12 \mathrm{~Gy} \mathrm{~cm}^{2}(11$ hospitals), $1.26 \mathrm{~Gy} \mathrm{~cm}^{2}$ (8 hospitals) and $0.99 \mathrm{~Gy}$ $\mathrm{cm}^{2}$ (8 hospitals) [71-73]. As 50\% or more of the hospitals had a KAP lower than $1.0 \mathrm{~Gy} \mathrm{~cm}^{2}$, KAP values lower than $1.5 \mathrm{~Gy} \mathrm{~cm}^{2}$ should be easily attainable. This value is currently the (still conservative) Dutch DRL target [74]. It was used in calculations for 2017, together with a high voltage of $80 \mathrm{kV}$, an anode angle of $16^{\circ}, 3.5 \mathrm{~mm}$ Al total filtration and a $105-\mathrm{cm}$ focus-detector distance.

- Averages from two rooms in our hospital gave values for 2018; the technique parameters are given in Table 2 . The latter have essentially remained the 

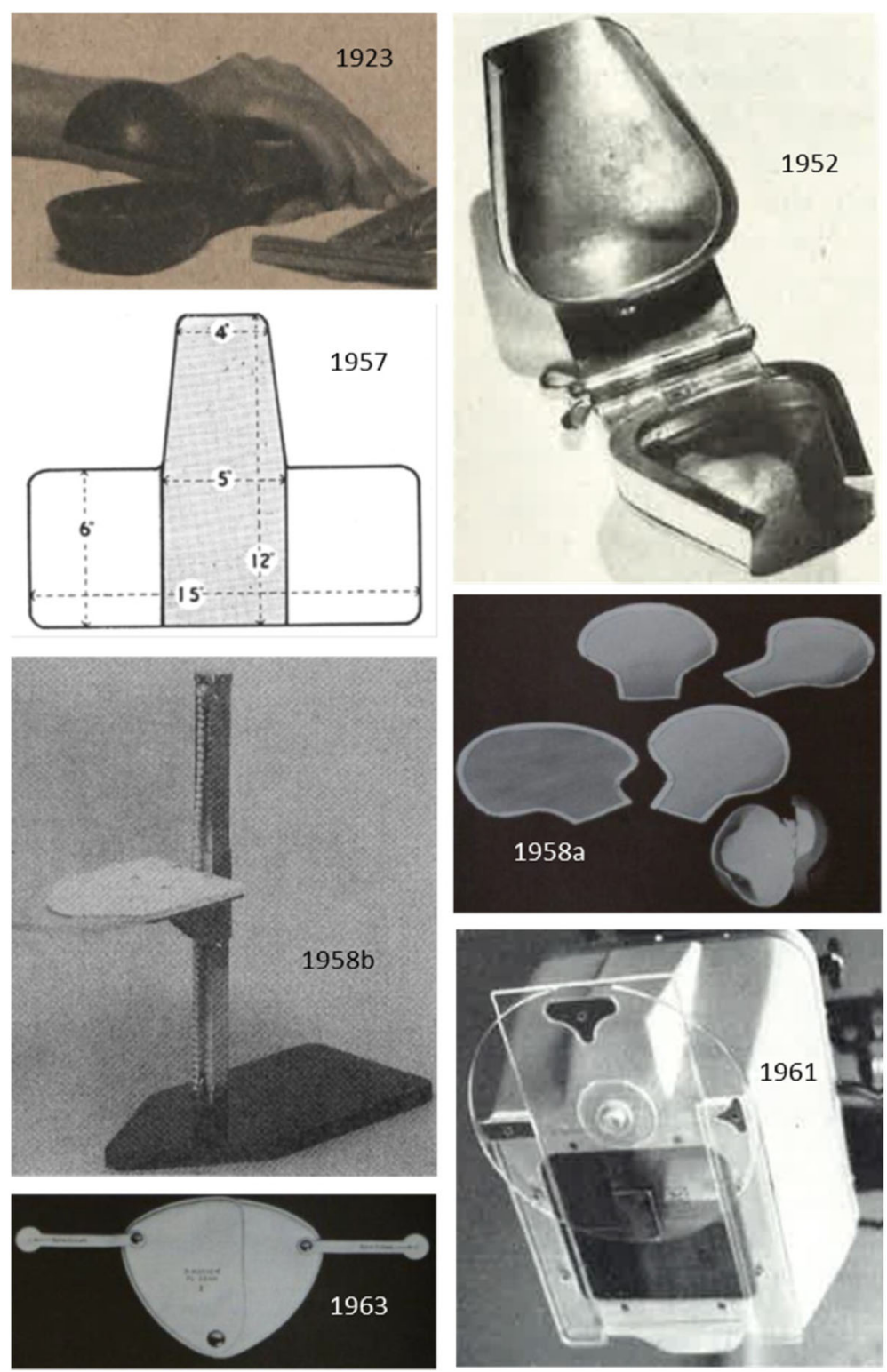

Fig. 1 Some early gonad shields with the year they were described in the literature. Testes capsules are seen on the photographs from 1923 [45], 1952 [46] and 1958a (at the right bottom of the image) [47]. A PMMA T-shaped board with 2-mm lead (shaded) for testes shielding is shown on the 1957 drawing [48]. Flexible contact-type shields for females are seen on the 1958a [47] and 1963 [55] images. The devices on the photos from 1958b [52] and 1961 [53] are of the projection type, the first to be positioned somewhere above the patient and the latter was fixed to the X-ray diaphragm

Table 2 Technique parameters AP pelvic radiography in our hospital (MUMC+ $)^{a}$

\begin{tabular}{llllllllll}
\hline Room & $n$ & $\mathrm{kVp}$ & Tube current & $t_{\text {exposure }}$ & Tube load & KAP & FID & KfiA & ESAK \\
\hline 1 & & & $\mathrm{~mA}$ & $\mathrm{~ms}$ & $\mathrm{~mA} . \mathrm{s}$ & $\mathrm{Gy} \mathrm{cm}$ & $\mathrm{cm}$ & $\mathrm{mGy}$ & $\mathrm{mGy}$ \\
2 & 110 & $85 \pm 0$ & $472 \pm 2$ & $49 \pm 28$ & $23 \pm 13$ & $0.70 \pm 0.41$ & $142 \pm 7$ & $0.61 \pm 0.36$ & $0.91 \pm 0.54$
\end{tabular}

${ }^{\mathrm{a}}$ Inherent filtration X-ray tube $3 \mathrm{~mm} \mathrm{Al}$, added filtration $0.1 \mathrm{~mm} \mathrm{Cu}$, anode angle $16^{\circ}$, a 25 -cm distance from skin on X-ray entrance side to image receptor is assumed, backscatter factor 1.49

KAP kerma area product, FID ray focus to image receptor distance, KfiA kerma free in air at entrance position on skin (patient removed), ESAK entrance surface air kerma including backscatter (=KfiA $\times$ backscatter factor) 
same since 2011 to the apparent satisfaction of the radiological staff [7]. For general information on dose reduction in digital radiography by $\mathrm{Cu}-$ filtration, see, e.g. Martin [75] and Kawashima [76].

\section{Optimisation of AP pelvic radiography}

The potential for optimisation was assessed starting from European data presented in: "Medical Radiation Exposure of the European Population, Radiation Protection report No 180" [70, 77], hereafter referred to as RP180. The final documents are from 2015, reporting data collected in surveys during 2007-2010. Amongst other data, RP180 provides the annual frequency and effective dose of several X-ray examinations for 35 countries in Europe (573 million inhabitants; data for Latvia are missing). Figure 2 shows data for radiography of the pelvis.
The effective dose data in Fig. 2 (bottom), being from 2007 to 2010, will partly stem from screen-film systems, generally with a speed of about 400, and partly from digital systems often also set at speed 400. For skeletal (including pelvic) radiography, however, speed 800 with image quality (nearly) equalling speed 400 screen-film may have been used [78].

The potential of dose optimisation is illustrated by calculating the cumulative effective dose from all EU countries for four levels of optimisation. First, the RP180 data as reported [77] are used. In the second scenario, all European countries are supposed to expose pelvic radiographs at the level of the most common DRL in Europe, i.e. a KAP of $3.0 \mathrm{~Gy} \mathrm{~cm}^{2}$ [70]. In scenario 3 , the exposure level equals the already discussed Dutch target DRL, i.e. a KAP of 1.5 Gy $\mathrm{cm}^{2}$, and in scenario four all exposure parameters are again taken from our hospital (Table 2). In all four

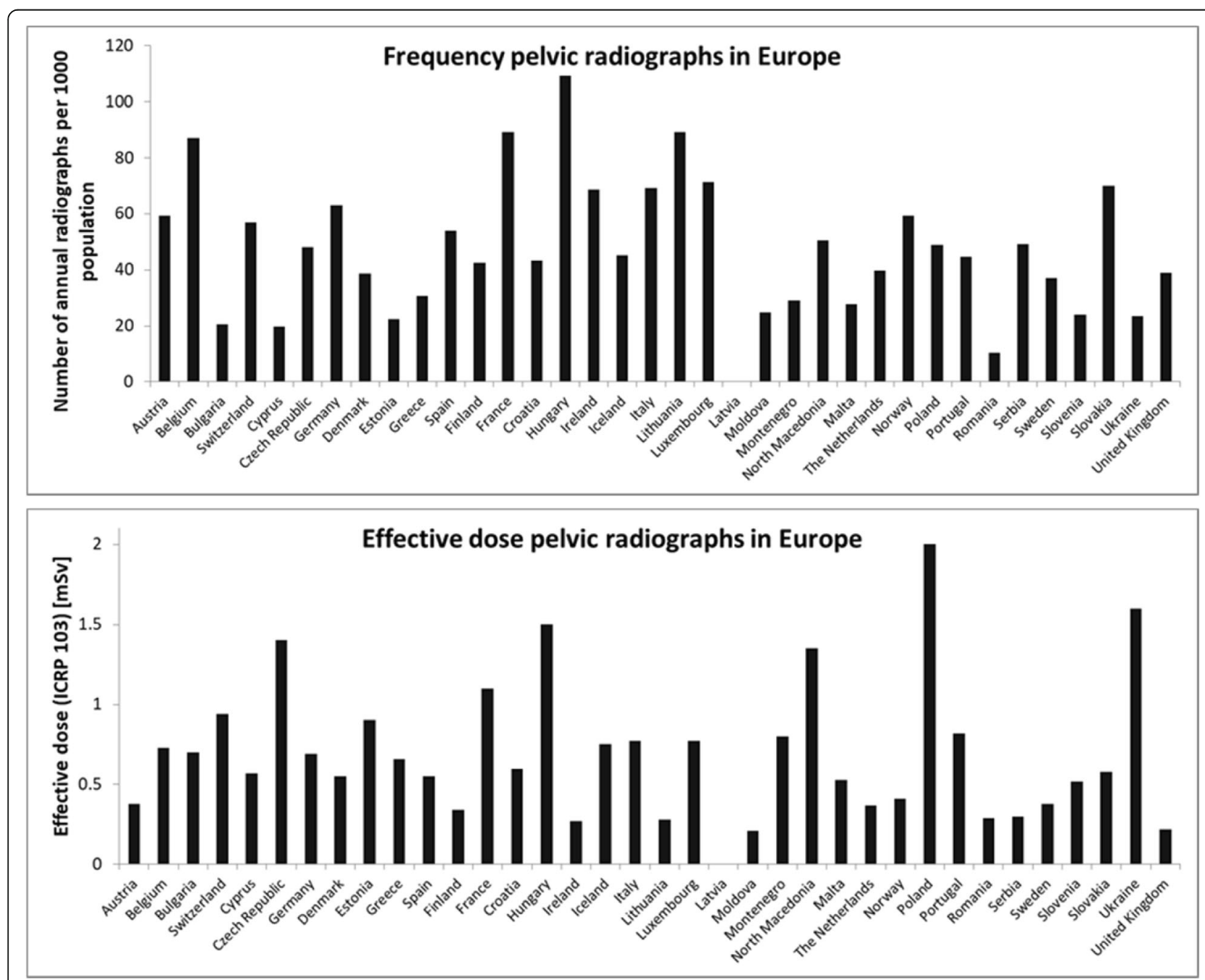

Fig. 2 Annual frequency of pelvic radiographs per 1000 population in European countries (top). Effective dose of pelvic radiographs in European countries (bottom). According to RP180, data from 2007 to 2010 [77] 
scenarios, the national pelvic radiograph frequencies remained as reported in RP180.

In a fifth scenario, the radiograph frequency was harmonised by setting it for all countries to the Dutch value, while national effective doses as reported in RP180 were used. For justification of using Dutch references, see [79]. Looking at effective dose makes sense because gonad doses roughly scale with it: the absorbed dose of the testes varies between 8 and 14 times the effective dose, the ovary dose between 1 and 2.5 times as will be shown hereafter.

\section{Effect of gonad shielding on health risk}

The motivation for reintroducing gonad shielding in the 1950s was reduction of hereditary risk. Risk caused by radiation is commonly assessed as a "detriment-adjusted risk", which weighs not only life lost from fatal cancers and heritable effects, but also takes the reduced quality of life due to non-fatal cancers and heritable effects into account [80]. Around 2011, Frantzen et al. performed such a risk assessment for children [7]. Here it is done for adults and the exposure conditions described under "Radiation dose of an AP pelvic radiograph over time".

In our calculations, $5.40 \times 10^{-3} \mathrm{~Sv}^{-1}$ was used as the detriment-adjusted nominal risk coefficient for heritable disease [35]. This value holds for the reproductive population for which shielding is relevant. As risk for cancer the value for the whole population, $5.5 \times 10^{-2} \mathrm{~Sv}^{-1}$, was taken [35]. Gonad shields were assumed to have the (optimal) protection factors of 0.95 for the testes and 0.5 for the ovaries [59].

\section{Results}

Radiation dose of an AP pelvic radiograph over time

Figure 3 shows all dose data, reconstructed and retrieved, as "entrance surface air kerma including backscatter" (ESAK) [61]. An enormous spread in dose can be observed at all times and an average dose decrease between 1896 and 2018 by a factor of about 400 .

Table 3 shows doses over time, with at its bottom the dose reduction that has been achieved since 1905. Note that the relative reduction in ESAK is different from that in KAP due to differences in backscatter factor and focus-skin distance.

\section{Optimisation of AP pelvic radiography}

Table 4 shows collective effective doses in Europe for different degrees of optimisation. Note that "optimisation" may include the installation of a modern high-power, digital system. Scenario 4 illustrates that such a modern system, properly optimised, can lower the European collective effective dose by a factor of nine compared to the value calculated using RP180 data from 2007 to 2010. Scenario 5 in Table 4 shows that harmonising the frequency of pelvic radiographs in all European countries to the Dutch value of 39.8 per 1000 persons, results in a dose reduction of nearly $30 \%$. The average frequency in Europe was 54.3 per 1000 persons.

\section{Effect of gonad shielding on health risk}

Table 5 shows the strong decrease in detriment-adjusted risk resulting from technological developments and optimisation. Today, even assuming optimal shielding and

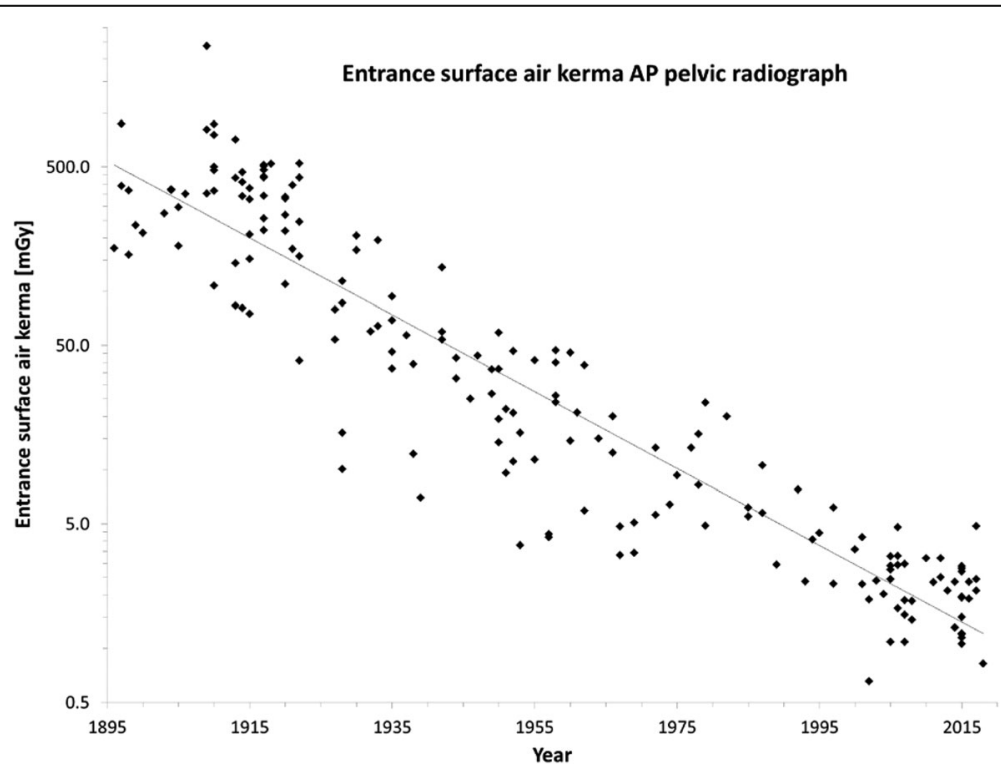

Fig. 3 Entrance surface air kerma including backscatter of an AP pelvic radiograph over the years $(n=182)$. Please note the logarithmic $y$-axis. The solid line is a fit of a simple exponential function to all data ("exponential regression") [61] 
Table 3 Mean dose data AP pelvic radiograph in absence of gonad shielding

\begin{tabular}{|c|c|c|c|c|c|c|}
\hline \multirow[t]{2}{*}{ Year } & \multirow[t]{2}{*}{ Source of data } & \multirow{2}{*}{$\begin{array}{l}\text { ESAK } \\
\text { (mGy) }\end{array}$} & \multirow{2}{*}{$\begin{array}{l}\text { KAP } \\
(\text { Gy } \\
\left.\mathrm{cm}^{2}\right)\end{array}$} & \multirow{2}{*}{$\begin{array}{l}\text { Effective } \\
\text { dose } \\
\text { (ICRP } \\
103) \\
\text { (mSv) }\end{array}$} & \multicolumn{2}{|l|}{ Absorbed dose } \\
\hline & & & & & Testes $^{a}$ (mGy) & Ovaries $^{a}(m G y)$ \\
\hline 1905 & 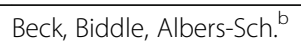 & 341 & 173 & 11.4 & 149 & 13 \\
\hline 1958 & Janker, Lincoln ${ }^{b}$ & 25 & 15.4 & 1.32 & 15 & 2.1 \\
\hline 2010 & "European" DRL" & 5.4 & 3.0 & 0.52 & 4.5 & 1.2 \\
\hline 2017 & Dutch target DRL ${ }^{d}$ & 2.7 & 1.5 & 0.26 & 2.3 & 0.61 \\
\hline \multirow[t]{2}{*}{2018} & MUMC+ & 0.82 & 0.55 & 0.095 & 0.74 & 0.24 \\
\hline & Dose 2018/Dose1905 & $0.22 \%$ & $0.26 \%$ & $0.86 \%$ & $0.48 \%$ & $2.0 \%$ \\
\hline
\end{tabular}

ESAK entrance surface air kerma which includes backscatter (dose in air but on the skin) [61], KAP product of kerma free in air and area of primary X-ray beam, $D R L$ diagnostic reference level

${ }^{a}$ With optimal shielding, these doses might be reduced by about $95 \%$ and $50 \%$, respectively

${ }^{b}$ Pulsed voltages were used. The equivalent DC voltage was calculated on the basis of effective dose in the same way as kV peak was converted to DC-kV on the

basis of kerma free in air [61]

${ }^{c}$ Most common DRL in Europe (KAP $=3.0 \mathrm{~Gy} \mathrm{~cm}^{2}$ ) [70]

${ }^{\mathrm{d}}$ Conservative Dutch target DRL (KAP $\left.=1.5 \mathrm{~Gy} \mathrm{~cm}^{2}\right)[74]$

no negative side-effects as done for Table 5, gonad shielding causes a very small reduction in risk only.

\section{Discussion}

When AP pelvic radiography is performed with modern and optimised X-ray systems, the reduction in hereditary risk by gonad shielding in women is so small that shielding can safely be discontinued. For men, the risk reduction can be larger but is still so small that it is doubtful whether the benefits outweigh the potential negative side-effects of using a shield. Several factors led to this state of affairs.

First, technological developments enabled an enormous reduction in the dose needed for a pelvic radiograph, as illustrated in Fig. 3 and Table 3. All dose cutbacks either directly resulted from these advances (e.g. higher sensitivity of image receptors and digital image processing) or were facilitated by them (e.g. higher power allowed increase of focus-patient distance and more filtration).

Second, optimisation lowered doses still further as shown by numerous studies as well as Table 4. Unfortunately, this potential has never adequately been exploited as illustrated by the large spread in Fig. 3 (at all times!) and Fig. 2 (around 2010). This is something the radiological profession should take to heart given longstanding guidance and legislation. The "As Low As Reasonably Achievable" (ALARA) principle goes back to 1966 [81], the requirement to optimise is from 1973 [82]. The large variability in frequency of pelvic radiographs reported in EU report RP180 for comparable EU countries is also unsatisfactory (Fig. 2, top), especially because 17 countries answered the question "Does the reimbursement system affect the frequency of examinations?" with "yes". This seems to imply that earnings affect study justification. An identical frequency of pelvic radiographs throughout the EU, equal to the Dutch value, could already lower the collective effective dose by $29 \%$.

Third, more recent insights into radiation biology have led to lower estimates of hereditary risks. According to current understanding, radiation-induced mutations generally do not come to expression in descendants, because, in the words of ICRP 103: "Most radiationinduced mutations are large multigene deletions, which are more likely to cause multisystem developmental abnormalities rather than single-gene (i.e., Mendelian)

Table 4 Cumulative effective dose caused by AP pelvic radiography in 35 European countries

\begin{tabular}{|c|c|c|c|c|}
\hline Scenario & Source effective dose per radiograph & $\begin{array}{l}\text { Source of annual frequency of } \\
\text { pelvic radiographs (RP180) }\end{array}$ & $\begin{array}{l}\text { Cumulative effective } \\
\text { dose }^{a}, \text { kmanSv }\end{array}$ & $\overline{\text { Percentage }}$ \\
\hline 1 & Individual countries (RP180) ${ }^{b}$ & Individual countries & 26.4 & $\equiv 100$ \\
\hline 2 & "European" DRL (RP180) & $"$ & 16.1 & 61 \\
\hline 3 & Dutch target $\mathrm{DRL}{ }^{\mathrm{c}}$ & $"$ & 8.0 & 30 \\
\hline 4 & MUMC+ & $"$ & 3.0 & 11 \\
\hline 5 & Individual countries (RP180) & The Netherlands (RP180) ${ }^{d}$ & 18.7 & 71 \\
\hline
\end{tabular}

${ }^{a}$ Cumulative effective dose is the sum of the effective dose over all exposed persons in the 35 countries ( $\mathrm{k}$ in kman-Sv stands for kilo, i.e. 1000)

${ }^{\mathrm{b}}$ Assuming AP projection dominates pelvic effective dose given in RP180

${ }^{c}$ Most common DRL in Europe is a KAP of $3.0 \mathrm{~Gy} \mathrm{~cm}^{2}$, also in the Netherlands [70]. The Dutch target is $1.5 \mathrm{~Gy} \mathrm{~cm}^{2}$, however [74]

${ }^{d}$ The annual frequency of pelvic radiographs in the Netherlands is 39.8 per 1000 population [77] 
Table 5 Detriment-adjusted risks for adults of reproductive age caused by AP pelvic radiography

\begin{tabular}{|c|c|c|c|c|c|c|c|}
\hline \multirow[t]{3}{*}{ Year } & \multirow{3}{*}{$\begin{array}{l}\text { Origin of data at basis } \\
\text { of calculation }\end{array}$} & \multicolumn{2}{|c|}{ Total risk X-ray without shielding ${ }^{a}$} & \multicolumn{2}{|c|}{ Total risk X-ray with shielding ${ }^{b}$} & \multicolumn{2}{|c|}{ Reduction risk by shielding gonads } \\
\hline & & Males & Females & Males & Females & Males & Females \\
\hline & & per $10^{6}$ & per $10^{6}$ & per $10^{6}$ & per $10^{6}$ & per $10^{6}$ & per $10^{6}$ \\
\hline 1905 & Beck, Biddle, Albers-Sch & 1075 & 341 & 308 & 307 & 767 & 35 \\
\hline 1958 & Janker, Lincoln & 116 & 47 & 39 & 41 & 77 & 5.6 \\
\hline 2010 & "European" DRL ${ }^{\mathrm{d}}$ (RP180) & 40 & 23 & 17 & 19 & 23 & 3.3 \\
\hline 2017 & Dutch target $D R L^{d}$ & 20 & 11 & 8.5 & 9.7 & 12 & 1.7 \\
\hline 2018 & MUMC+ & 8.6 & 5.4 & 4.0 & 4.6 & 4.6 & 0.77 \\
\hline
\end{tabular}

${ }^{a}$ Using abbreviations $R=$ detriment-adjusted risk, $E=$ effective dose and $H=$ equivalent dose, the risk was approximated as $R_{\text {male }}=5.5 \times 10^{-2} \times\{E-0.04 \times$ $\left.\left(H_{\text {Testes }}+H_{\text {Ovaries }}\right)\right\}+5.4 \times 10^{-3} \times H_{\text {testes }}$ and analogously for females. Applied for instance to "1958 males without shielding", this gives $R_{\text {male }}=5.5 \times 10^{-2} \times\{1.32 \times$ $\left.10^{-3}-0.04 \times\left(15 \times 10^{-3}+2.1 \times 10^{-3}\right)\right\}+5.4 \times 10^{-3} \times 15 \times 10^{-3}=116 \times 10^{-6}$. Note that we used data from Table 3 and that the equivalent dose equals the absorbed dose multiplied by the relative biological effectiveness of the radiation causing the absorbed dose. For X-rays, this factor is 1 Sv/Gy, so absorbed and equivalent dose are numerically equal

${ }^{\mathrm{b}}$ With gonad shielding, the last term in $R_{\text {male }}$ is modified into: $5.4 \times 10^{-3} \times(1-\mathrm{GS}) \times H_{\text {Testes, }}$ with GS the shielding factor of 0.95 for males. Analogously for females, but with GS $=0.5$

"Decrease in total risk resulting from the reduction in hereditary ("gonad") risk by shielding

${ }^{\mathrm{d}}$ Most common European DRL, i.e. KAP $=3.0 \mathrm{~Gy} \mathrm{~cm}^{2}$; Dutch target DRL is KAP $=1.5 \mathrm{~Gy} \mathrm{~m}^{2}$

diseases. Importantly, only a fraction of these are likely to be compatible with live births.", and "Nearly all chronic diseases have a genetic component, but because most of these are multigenic and multifactorial, the mutation component (i.e., the responsiveness of these diseases to an alteration in mutation rate) is small, so that chronic diseases respond only minimally to a radiationinduced increase in mutation rate" [35].

The effectiveness of diagnostic reference levels (DRLs) in optimisation may need a closer look. DRLs were introduced by the ICRP in 1990 [38] and further addressed in 1996 [83], 2001 [84] and 2017 [85]. The Euratom Council Directive from 2013 [86] reiterated the importance of DRLs, and the European Society of Radiology (ESR) tried (and tries) to help their implementation in radiological practice with their programme "Eurosafe Imaging" [87]. Success can be claimed to the extent that DRLs were applied in about 80 to $90 \%$ of the institutions surveyed by the ESR in 2019 [88]. However, by its approach, i.e. setting the 75 percentile of the dose distribution at some time as the DRL and then "correcting" the systems with doses higher than the DRL-after which the whole cycle should be repeated-the average dose decreases only very slowly. A recent (2019) and large study by Schegerer et al. [89] may be seen as illustrative: nearly 30 years after the introduction of the DRL, the ratio of the 25th and 75th percentiles for "pelvis AP/PA" (and most other conventional X-ray projections) still exceeded a factor 2, signalling a broad distribution of doses (in line with Fig. 3). In conclusion, local optimisation, which for instance resulted in the technique parameters of Table 2, is probably much more efficient than following the DRL approach. The strength of DRLs is eliminating bad practices.

The question remains how to proceed with gonad shielding. Several studies pointed to inadequate placement of gonad shields, the concomitant loss of diagnostic information and the low doses currently involved, but were cautious with their advice. A few suggest reconsidering or ending the practice in female children [6-9, 11-13], in male children [7, 9, 12] or in all $[3,10]$. Marsh and Silosky are more outspoken when referring to the officially still endorsed practice of gonad shielding as "...the folly of its continued use..." [4]. They question the linear-no-threshold model and the cumulative nature of small doses, maybe rightly, but in our opinion, it is wise to abide by the prevailing views disseminated by the international organisations in the radiation protection field. Marsh and Silosky further argue that the benefits are small or non-existent and that shielding involves considerable risks. Risks certainly exist, but unfortunately they are very difficult to assess in a quantitative way. Reported negative effects ("risks") of shielding include [7] the following: testes dose reduction of less than $95 \%$ due to misplaced shields (e.g. $77 \%$ in 10-15-year olds) [7], the need of retakes (Gürsu et al. reported a retake rate of $3 \%$ in children up to 17 years) [90], a dose increase if the shield covers (part of) the automatic exposure control (AEC) detector [13], and loss of diagnostic information, and distraction of the technologist by handling the shield. The small risk reductions seen at the bottom of Table 5 (a risk $<1 \times 10^{-6}$ is considered inconsequential [91]) have to be viewed in the light of such effects. Note also that these reductions are only obtained under ideal shielding circumstances. For females, the conclusion is straightforward, but for males it is less obvious. Given the information above, and that the AEC detector generally is not behind the (shielded) testes, it is hardly to be expected that poor positioning, retakes and AEC coverage would decrease the (average) male shielding-factor from 0.95 to below 0.5. The benefit of shielding shown in Table 5 might then 
actually be up to about $50 \%$ lower. But other, probably rare effects caused by information loss and user distraction may be more important. Two hypothetical examples might give an idea of what could go wrong due to using a gonad shield. A seldom, but not impossible, fatal accident could be the missing of a Ewing sarcoma in the pubic bone of a boy with pain in his groin because the shield covered the lesion. Or an infant, or an unconscious person, could tumble from the table because the radiographer was picking up a shield lying outside his reach before some fixation of the patient was arranged. But how often will such or other serious incidents happen? Or how often, and how seriously, will shielding hamper diagnostic evaluation? One does not know, and although this is clearly a limitation of the study, it is evident that harm is possible and that already very few incidents per million radiographs would undo the small benefit calculated in Table 5 .

After discontinuing gonad shielding, as our hospital already did in 2011, patients (or their parents) may perceive not using a shield a serious neglect. They must therefore be informed and possibly reassured, for instance by giving examples of effective doses of a similar magnitude received during common activities (see, e.g. [7], Table 7). In our experience, not shielding quickly becomes the new standard.

\section{Conclusions}

Modern equipment and optimisation are keys to reducing radiation risk in pelvic radiography. When their full potential is exploited, the decrease in detriment-adjusted risk achievable by gonad shielding is so small that, in the light of negative side-effects, ending the practice seems justifiable.

\footnotetext{
Abbreviations

AAPM: American Association of Physicists in Medicine; AEC: Automatic exposure control; ALARA: As Low as Reasonably Achievable; AP: Anteroposterior; DRL: Diagnostic reference level; E: Effective dose; ESAK: Entrance surface air kerma (dose in air at the skin, including backscatter); EU: European Union; FID: X-ray focus to image receptor distance; GSD: Genetically significant dose; $\mathrm{H}_{\mathrm{E}}$ : Effective dose equivalent; IAEA: International Atomic Energy Agency; ICRP: International Commission on Radiological Protection; KAP: Product of kerma free in air and X-ray beam area; KfiA: Kerma free in air; MUMC+: Maastricht University Medical Center; PCXMC: A Monte Carlo programme for calculating patient doses in medical x-ray examinations; PMMA: Polymethylmethacrylate (Acrylic, Lucite, Perspex); R: Detriment-adjusted risk; RP180: Medical Radiation Exposure of the European Population, EU Report 180 (2015); UNSCEAR: United Nations Scientific Committee on the Effects of Atomic Radiation
}

\section{Acknowledgements}

The authors are indebted to Dr. Kees Simon for his assistance and to the Siemens Healthineers MedMuseum in Erlangen for access to their large collection of documents and literature.

\section{Authors' contributions}

The study was designed by GJK. CRLPNJ collected all data from our hospital. All authors helped in searching for data in the literature or contributed to the preparation of the manuscript, and they all read and approved the final manuscript.

\section{Authors' information}

None

Funding

None

Availability of data and materials

References are given for all data, except for the dose data on pelvic radiography originating from our own hospital. The latter are available from the first author.

Ethics approval and consent to participate

Not applicable

\section{Consent for publication}

Not applicable

\section{Competing interests}

JEW has institutional grants, all outside submitted work, from Agfa, Bayer, GE, Optimed, Philips, Siemens. Speaker's bureau: Bayer, Siemens

Received: 13 October 2019 Accepted: 10 December 2019

Published online: 07 February 2020

\section{References}

1. ICRP, Khong PL, Ringertz $\mathrm{H}$ et al (2013) ICRP Publication 121: Radiological protection in paediatric diagnostic and interventional radiology. Ann ICRP 42:1-63

2. IAEA (2018) Radiation protection and safety in medical uses of ionizing radiation. International Atomic Energy Agency, Vienna

3. NVMBR (2017) Richtlijn Gonadenafscherming voor conventionele radiologie en CT. Utrecht. Available via https://www.nvmbr.nl/publicatiebestanden/ NVMBR\%20Richtlijn\%20Gonadenafscherming\%20mei\%202017.pdf

4. Marsh RM, Silosky M (2019) Patient shielding in diagnostic imaging: discontinuing a legacy practice. AJR Am J Roentgenol 212:755-757 https:// doi.org/10.2214/AJR.18.20508

5. AAPM (2019) AAPM Position Statement on the Use of Patient Gonadal and Fetal Shielding PP32-A. Available via https://www.aapm.org/org/policies/ details.asp?id=468\&type $=P P$

6. Fawcett SL, Gomez AC, Barter SJ, Ditchfield M, Set P (2012) More harm than good? The anatomy of misguided shielding of the ovaries. Br J Radiol 85: e442-e447 https://doi.org/10.1259/bjr/25742247

7. Frantzen MJ, Robben S, Postma AA, Zoetelief J, Wildberger JE, Kemerink GJ (2012) Gonad shielding in paediatric pelvic radiography: disadvantages prevail over benefit. Insights Imaging 3:23-32 https://doi.org/10.1007/ s13244-011-0130-3

8. Warlow T, Walker-Birch P, Cosson P (2014) Gonad shielding in paediatric pelvic radiography: Effectiveness and practice. Radiography 20:178-182 https://doi.org/10.1016/j.radi.2014.01.002

9. Lee MC, Lloyd J, Solomito MJ (2017) Poor utility of gonadal shielding for pediatric pelvic radiographs. Orthopedics 40:e623-e627 https://doi.org/10. 3928/01477447-20170418-03

10. Strauss KJ, Gingold EL, Frush DP (2017) Reconsidering the value of gonadal shielding during abdominal/pelvic radiography. J Am Coll Radiol 14:16351636 https://doi.org/10.1016/j.jacr.2017.06.018

11. Kumar A, Chau WW, Hung AL-H, Wong JK-T, Ng BKW, Cheng JCY (2018) Gonadal shield: is it the Albatross hanging around the neck of developmental dysplasia of the hip research? J Child Orthop 12:606613 https://doi.org/10.1302/1863-2548.12.180133

12. Karami V, Zabihzadeh M, Shams N, Sarikhani S (2016) Evaluation of the prevalence and utility of gonad shielding in pediatrics undergoing pelvic X-ray Int J Pediatr 4(11):3735-3740 https://doi.org/10.22038/ijp.2016.7589

13. Kaplan SL, Magill D, Felice MA, Xiao R, Ali S, Zhu X (2018) Female gonadal shielding with automatic exposure control increases radiation risks. Pediatr Radiol 48:227-234 https://doi.org/10.1007/s00247-017-3996-5

14. Marcuse W (1896) Nachtrag zu dem Fall von Dermatitis und Alopecie nach Durchleuchtungsversuchen mit Röntgenstrahlen. Dtsch Med Wochenschr 22:481-483 
15. Hönigsmann $H$ (2013) History of phototherapy in dermatology. Photochem Photobiol Sci 12:16-21 https://doi.org/10.1039/C2PP25120E

16. Williams FH (1901) The roentgen rays in medicine and surgery. The Macmillan Company, New York

17. Hyde JN (1903) A contribution to the subject of radiotherapy and phototherapy in carcinoma, tuberculosis and other diseases of the skin. JAMA XL(1):1-8. https://doi.org/10.1001/jama.1903.92490010001001

18. Bullitt JB (1905) Comparison of Röntgen-ray and surgical treatment of tuberculosis. Trans Am Röntgen Ray Soc. (Fifth annual meeting, St Louis), p 26-34

19. Pennington JR (1904) Roentgen rays in the treatment of pruritis ani. N Y Med J Phila Med J 89:356-358

20. Brown FT, Osgood AT (1905) X-rays and sterility. Am J Surg 18:179-182

21. Despeignes $V(1896)$ Observation concernant un cas cancer de l'estomac, traités par les rayons röntgens. Lyon Méd J 82:428-430

22. Albers-Schönberg HE (1903) Ueber eine bisher unbekannte Wirkung der Röntgenstrahlen auf den Organismus der Tiere. Muench Med Wochenschr 50:1859-1860

23. Halberstaedter L (1905) Die Einwirkung der Röntgenstrahlen auf Ovarien. Berl Klin Wochenschr 42:64-66

24. Bardeen CR (1907) Abnormal development of toad ova fertilized by spermatozoa exposed to the Roentgen rays. J Exp Zool 4:1-44 https://doi. org/10.1002/jez.1400040102

25. Muller HJ (1927) Artificial transmutation of the gene. Science 66:84-87 https://doi.org/10.1126/science.66.1699.84

26. Mavor JW (1921) On the Elimination of the X-chromosome from the egg of Drosophila melanogaster by X-rays. Science 54:277-279 https://doi.org/10. 1126/science.54.1395.277

27. Witte E (1933) Welche Mittel gibt es, um bei diagnostischer Verwendung der Röntgenstrahlen die Dosis zu vermindern? Fortschritte auf dem Geb Röntgenstrahlen 47:312-321

28. Neeff TC (1934) Über Strahlendosen bei der Röntgenkymographie in der Schwangerschaft. Fortschritte auf dem Geb Röntgenstrahlen 50:86-90

29. Zimmer KG (1935) Über Dosismessungen während Röntgendiagnostik Fortschritte auf dem Geb Röntgenstrahlen 51:418-421

30. Griffith HD, Zimmer KG (1935) The time-intensity factor in relation to the genetic effects of radiation. Br J Radiol 8:40-47 https://doi.org/10.1259/0007-1285-8-85-40

31. Pickhan A (1936) Welche Strahlendosen dürfen bei der Röntgendiagnostik der weiblichen Zeugungsorgane nach den Ergebnissen der experimentellen Strahlengenetik in erbbiologischem Sinne als unschädlich betrachtet werden? Fortschritte auf dem Geb Röntgenstrahlen 53:901-904

32. ICRP (1959) 1958 Recommendations of the International Commission on Radiological Protection. Ann ICRP 1(1), iii-x

33. UNSCEAR (1958) UNSCEAR. General Assembly. Official Records. Thirteenth session. Supplement No17 (A3838). New York

34. ICRP (1970) Protection of the patient in X-ray diagnosis. ICRP Publication 16 Pergamon Press, Oxford

35. ICRP (2007) The 2007 Recommendations of the International Commission on Radiological Protection. ICRP Publication 103. Ann ICRP 37 (2-4).

36. Frik W (1960) Gesamtbelastung als Maß für die Strahlengefährdung. Röntgen-Bl 13:166-172

37. ICRP (1977) Recommendations of the ICRP. ICRP Publication 26. Ann ICRP 1(3):1-53

38. ICRP (1991) 1990 Recommendations of the International Commission on Radiological Protection. ICRP Publication 60. Ann ICRP 21 (1-3).

39. Holzknecht G, Grünfeld R (1903) Ein neues Material zum Schutz der gesunden Haut gegen Röntgenlicht und über radiologische Schutzmassnahmen im Algemeinen. Münch Med Wochenschr 50:1202-1205

40. Cramer M (1905) Über die Behandlung der Leukämie mit Röntgenstrahlen. Fortschritte auf dem Geb Röntgenstrahlen 9:115-117

41. Kienböck R (1907) Radiotherapie. Ferdinand Enke, Stuttgart

42. Albers-Schönberg H, Walter B (1910) Die Röntgentechnik, third. Lucas Gräfe \& Sillem, Hamburg

43. Albers-Schönberg (1941) Die Röntgentechnik, 6th ed. Georg Thieme, Leipzig

44. ICRP (1955) Supplement No. 6. Recommendations of the International Commision on Radiological Protection. Br J Radiol 1-92

45. Kriser A (1923) Einige technische Verbesserungen bei der Tiefenbestrahlung - Behelfe und Schutzvorrichtungen bei Bestrahlung der Keimdrüsen und ihrer Umgebung. Verhandlungen Dtsch Röntgen-Ges 14:115-118

46. Magnusson W (1952) A device for the protection of the testicle in roentgen examinations of adjacent organs and bones. Acta Radiol 37: 288-290
47. Lorenz W (1958) Physikalisch-technische Probleme des Strahlenschutzes in medizinische Anlagen. Fortschritte auf dem Geb Röntgenstrahlen 88: 251-276

48. Ardran GM, Kemp FH (1957) Protection of the male gonads in diagnostic procedures. Br J Radiol 30:280-280 https://doi.org/10.1259/0007-1285-30-353-280

49. Stieve FE (1959) Untersuchungen über Maßnahmen zur Reduzierung der Strahlenbelastung der männlichen Keimdrüsen bei röntgendiagnostischen Maßnahmen in deren Umgehung. Fortschritte auf dem Geb Röntgenstrahlen 90:373-386

50. Abram E, Wilkinson DM, Hodson CJ (1958) Gonadal Protection from X radiation for the Female. Br J Radiol 31:335-336 https://doi.org/10.1259/ 0007-1285-31-366-335

51. Krepler P, Vana N, Havranek C (1977) Dosimetric studies in the radiological examination of the hips in young infants with a special fenestration method of gonad protection. Pediatr Radiol 5:231-235

52. Hodges PC, Strandjord NM, McCrea A (1958) A testicular shield. J Am Med Assoc 167:1239 https://doi.org/10.1001/jama.1958.72990270008009b

53. Whitehead G, Griffiths JT (1961) The Leicester gonad protector: a device to afford localised protection from diagnostic x irradiation. Br J Radiol 34:135-136 https://doi.org/10.1259/0007-1285-34-398-135

54. Correll R, Plischke U, Dresel H, Joos M (1976) Gonadenschutz bei Beckenaufnahmen. Röntgen-BI 29:137-142

55. Büchner H, Wendrich G (1963) Über einen neuen variablen Ovarienschutz bei Röntgenaufnahmen des Beckens. Röntgen-BI 16:385-394

56. Markó D (1962) Gonadenschutz (Gonad-Defensor), ein Tubus für Beckenaufnahmen. RöFo - Fortschritte auf dem Geb Röntgenstrahlen Bildgeb Verfahr 97:793-796 https://doi.org/10.1055/s-0029-1227140

57. Grigg ERN (1965) The trail of the invisible light. From X-Strahlen to Radio(bio)logy. Charles C. Thomas, Springfield, USA

58. Yousefzadeh DK, Ward M, Reft C, Pelizzari C (2006) Methods of attenuating internal radiation exposure. US patent 2006/0009694 A1. https://patentimages. storage.googleapis.com/9d/d3/ea/ee7ae848835a9c/US20060009694A1.pdf.

59. ICRP (1982) Protection of the patient in diagnostic radiology. ICRP Publication 34. Ann ICRP 9 (2-3)

60. Karami V, Zabihzadeh M, Shams N, Saki Malehi A (2017) Gonad shielding during pelvic radiography: a systematic review and meta-analysis. Arch Iran Med 20:113-123 https://doi.org/0172002/AlM.0011

61. Kemerink GJ, Kütterer G, Kicken PJ, van Engelshoven JMA, Simon KJ Wildberger JE (2019) The skin dose of pelvic radiographs since 1896. Insights Imaging 10:39 https://doi.org/10.1186/s13244-019-0710-1

62. Tapiovaara M, Siiskonen T (2008) Report - PCXMC: a Monte Carlo program for calculating patient doses in medical $x$-ray examinations, 2. ed. STUK, Helsinki

63. Tapiovaara M, Siiskonen T (2008) PCXMC: a Monte Carlo program for calculating patient doses in medical x-ray examinations. Helsinki, STUK Radiation and Nuclear Safety Authority

64. Beck C (1904) Röntgen ray diagnosis and therapy. D. Appleton and company, New York

65. Biddle JG (1904) Roentgen induction coils and other X-ray apparatus. James G Biddle, Philadelphia

66. Biddle JG (1905) Typical "Roentgen" Equipments. James G Biddle, Philadelphia

67. Albers-Schönberg, (1906) Die Röntgentechnik: Lehrbuch für Ärzte und Studierende, second. Lucas Gräfe \& Sillem, Hamburg

68. Janker HC (1958) Röntgen-Aufnahmetechnik. Teil I: Einstellungen. Johann Ambrosius Barth, München

69. Lincoln A, Gupton ED (1958) Radiation dose to gonads from diagnostic x-ray exposure. J Am Med Assoc 166:233-239

70. European Commission, Directorate-General for Energy (2015) Diagnostic Reference Levels in Thirty-six European Countries. RP 180 -Part 2/2. Publications Office, Luxembourg

71. RIVM (2015) Vervolgproject DRN toetsing:2015 https://www.rivm.nl/ medische-stralingstoepassingen/stralingsbescherming-pati-nten/ diagnostische-referentieniveaus/vervolgproject-drn-toetsing-2015.

72. RIVM (2016) Vervolgproject DRN toetsing:2016 https://www.rivm.nl/ medische-stralingstoepassingen/stralingsbescherming-pati-nten/ diagnostische-referentieniveaus/vervolgproject-drn-toetsing-2016.

73. RIVM (2017) Vervolgproject DRN toetsing:2017 https://www.rivm.nl/ medische-stralingstoepassingen/stralingsbescherming-pati-nten/ diagnostische-referentieniveaus/vervolgproject-drn-toetsing-2017.

74. Bijwaard H, de Vries G, Scheurleer J et al (2017) Compliance to Diagnostic Reference Levels for radiation exposure in common radiological procedures 
in Dutch hospitals: A nation-wide survey carried out by medical imaging students. Radiography 23:197-201 https://doi.org/10.1016/j.radi.2017.03.005

75. Martin C (2007) The importance of radiation quality for optimisation in radiology. Biomed Imaging Interv J 3(2) https://doi.org/10.2349/biij.3.2.e38

76. Kawashima H, Ichikawa K, Nagasou D, Hattori M (2017) X-ray dose reduction using additional copper filtration for abdominal digital radiography: Evaluation using signal difference-to-noise ratio. Phys Med 34:65-71 https:// doi.org/10.1016/j.jmp.2017.01.015

77. European Commission, Directorate-General for Energy (2015) Medical radiation exposure of the European population. RP 180 - Part 1/2. Publications Office, Luxembourg

78. Völk M, Hamer OW, Feuerbach S, Strotzer M (2004) Dose reduction in skeletal and chest radiography using a large-area flat-panel detector based on amorphous silicon and thallium-doped cesium iodide: technical background, basic image quality parameters, and review of the literature. Eur Radiol 14:827-834 https://doi.org/10.1007/s00330-004-2243-2

79. Health Consumer Powerhouse (2017) Euro Health Consumer Index:2017 https://healthpowerhouse.com/media/EHCl-2017/EHCl-2017-report.pdf.

80. Wall BF, Haylock R, Jansen JTM, Hillier MC, Hart D, Shrimpton PC (2011) Radiation risks from medical $x$-ray examinations as a function of the age and sex of the patient. Centre for Radiation, Chemical and Environmental Hazards, Health Protection Agency

81. ICRP (1966) Recommendations of the International Commission on Radiological Protection. ICRP Publication 9. Pergamon Press, Oxford

82. ICRP (1973) Implications of Commission Recommendations that doses be kept as low as readily achievable. ICRP Publication 22. Pergamon Press, Oxford.

83. ICRP (1996) Radiological Protection and Safety in Medicine. ICRP Publication 73. Ann ICRP 26(2):1-47

84. ICRP (2001) Diagnostic Reference Levels in medical imaging: review and additional advice. ICRP Supporting guidance 2. Ann ICRP 31:33-52

85. Vano E, Miller DJ, Martin CJ et al (2017) ICRP publication 135: Diagnostic Reference Levels in Medical Imaging. Ann ICRP 46:1-144 https://doi.org/10. $1177 / 0146645317717209$

86. European Union (2014) Council Directive 2013/59/Euratom of 5 December 2013 laying down basic safety standards for protection against the dangers arising from exposure to ionising radiation (L 13). Off J Eur Union 57:1-73

87. ESR Eurosafe Imaging website. http://www.eurosafeimaging.org/. Accessed 27 Nov 2019

88. European Society of Radiology (ESR) (2019) The Current Status of Uptake of European BSS Directive (2013/59/Euratom) Requirements - Results of a Pilot Survey in European Radiology Departments with a Focus on Clinical Audit. Insights Imaging 10:50 https://doi.org/10.1186/s13244-019-0734-6

89. Schegerer A, Loose R, Heuser L, Brix G (2019) Diagnostic Reference Levels for Diagnostic and Interventional X-Ray Procedures in Germany: Update and Handling. RöFo - Fortschritte auf dem Geb Röntgenstrahlen Bildgeb Verfahr 191:739-751 https://doi.org/10.1055/a-0824-7603

90. Gürsu S, Gürsu T, Camurcu Y, Yıldırım T, Gürsu A, Sahin V (2013) Efficacy of gonadal shielding in pediatric pelvis $X$-rays. Eklem Hastalık Ve Cerrahisi Jt Dis Relat Surg 24:87-90 https://doi.org/10.5606/ehc.2013.20

91. Valentin J (2005) ICRP 99. Low-dose extrapolation of radiation-related cancer risk. Ann ICRP 35:1-140 https://doi.org/10.1016/j.icrp.2005.11.002

\section{Publisher's Note}

Springer Nature remains neutral with regard to jurisdictional claims in published maps and institutional affiliations.

\section{Submit your manuscript to a SpringerOpen ${ }^{\circ}$ journal and benefit from:}

- Convenient online submission

- Rigorous peer review

- Open access: articles freely available online

- High visibility within the field

- Retaining the copyright to your article

Submit your next manuscript at $\boldsymbol{\nabla}$ springeropen.com 